\title{
Post-2015 개발의제와 녹색 ODA
}

\author{
한 근 식 (KOICA 기후변화환경실 과장)
}

\section{목 차}

1. 들어가며

2. POST-2015 개발 의제와 녹색성장

3. 녹색성장과 개도국

4. 녹색 ODA 개념 및 분류

5. 국제 사회 및 한국의 녹색 ODA 현황

6. 동아시아기후파트너십 성과 및 교훈

7. 향후 KOICA 녹색 ODA 방향

\section{1. 들어가며}

최근 개도국의 기후변화 대응 및 녹색성장 문제가 원조사업의 핵심 이슈로 대두되고 있다. 기후에 취약한 개도국은 자연재해, 농업생산성 감소 등 기후변화 대응 역량 및 인프라가 부족 하고 물과 위생, 에너지 부족 등은 개도국의 경제개발 및 $\mathrm{MDG}$ 달성을 저해하고 있다. 이에 급속한 경제성장 과정에 있는 개도국이 환경파괴의 기회비용을 줄이고 성장의 지속가능성을 제고토록, 국제사회의 녹색성장 추구의 목소리가 증대되고 있다.

2012년 국제사회는 리우환경회의(RIO+20)에서 2015년 종료되는 UN의 새천년 개발계획 (Millenium Development Goals, 이후 MDGs)를 대체하는 계획으로써 지속가능한 개발목표 (Sustainable Development Goal, 이후 SDGs)로의 전환을 논의 하였으며, OECD, UNEP, 
World Bank 등은 이러한 녹색경제 전환 및 저탄소 성장에 대한 지원 논의를 확대 하고 있다.

본 원고의 2장에서는 Post-2015 후속 개발 의제 상에서의 녹색 성장이 차지하는 시사점을 논의하고, 3 장에서는 개도국과 녹색성장의 연관 관계에 관해 자연자원의 의존적 경제 구조, 기후변화의 취약성, $\mathrm{MDG}$ 와의 연관관계 등에 대해 설명하고자 한다. 4장에서는 녹색성장의 이행을 위한 $\mathrm{ODA}$ 재원으로서 녹색 $\mathrm{ODA}$ 의 개념 및 분류에 대해 설명하고, 5 장과 6 장에서는 국제사회와 한국의 녹색 ODA 현황과 KOICA가 2009-2012년 수행한 한국 최초의 대표 녹색 $\mathrm{ODA}$ 사업인 동아시아기후파트너십 사업의 성과와 과제에 대해 설명한다. 7장은 향후 코이카 의 녹색 $\mathrm{ODA}$ 지원 방향에 대해 논의하고 본 고를 마치고자 한다.

\section{POST-2015 개발 의제와 녹색성장}

\section{1) 그간 경과 사항}

최근 리우 회의 20 주년을 맞는 ' 12 년 6월 Rio+20(유엔 지속가능발전 회의) 결의문(The Future We Want)에서 녹색경제(Green Economy) 체제와 지속가능개발을 위한 범지구적인 대응과제로서 기후변화가 새천년개발목표(MDGs) 전반에 미치는 영향 증대로 인한 총체적 개 발 패러다임의 필요성을 인식하고, 2015년 Post-MDGs의 후속체재로 지속가능한 개발목표 $(\mathrm{SDGs})$ 를 개발협력의 중심축으로 추진코자 하는 논의가 최종 결의문으로 채택되었다.

$\mathrm{SDGs}$ 는 Rio+20 회의 이전에 2011년 9월 콜롬비아 정부에 의해 제출된 방안으로 기존의 $\mathrm{MDGs}$ 가 개도국 중심의 목표를 넘어 전세계에 모든 국가에 적용가능한 글로벌 목표를 제시하 고 있다. 그러나 SDGs는 아이디어 형성 단계라 할 수 있으며, RIO+20에서 구체적 논의와 합 의를 기대하였으나, Rio+20 참가국은 $\mathrm{SDGs}$ 의 논의는 $\mathrm{MDGs}$ 논의의 장인 $\mathrm{UN}$ 총회로 넘겨 논 의키로 하였다(임소진, 2012)

2013년 3월 및 4월에 제1차, 제 2 차 유엔 SDGs 공개작업반 회의를 개최하고, 유엔 $\mathrm{UNDESA}$ 및 UNDP가 공동간사로 40여개 국제기구가 참여중인 SDGs 지원조직인 기술지원팀 (Technical Support Team)이 작성한 issues note를 토대로 SDGs 기본원칙, SDGs 와 MDGs 간의 관계, $\mathrm{SDGs}$ 구조(framework), 우선 분야(priority areas), 이행수단 및 모니터링 등 
SDGs의 개념적 이슈(conceptual issues)를 논의하였으며, 빈곤퇴치를 첫 번째 분야별(thematic) 이슈로 논의하였다. 아래 내용은 상기 회의에서 현재 논의된 사항을 정리하였으며, 향후 논의 사항은 작업반 회의가 2014년 2월까지 총 8차에 걸쳐 회원국과 작업일정 및 논의 주제 등을 협의해 나갈 예정이므로, 이에 따라 점차 SDGs의 윤곽이 구체화될 예정이다.

\section{2) 제2차 유엔 SDGs 작업반 논의 내용}

\section{$\mathrm{SDG}_{\mathrm{s}}$ 와 MDGs 간의 관계}

유엔기술지원팀 보고서는 $\mathrm{SDGs}$ 설정시 MDGs의 주요 교훈과 평가로서 아래 주요 사 항을 제시

- MDGs의 간결성은 빈곤퇴치를 위한 국제사회 모든 관련 행위자의 집결에 기여하고, 분명한 target 과 indicator를 통한 모니터링 및 책임성 제고

- MDGs는 목표 달성의 구체 행동을 명시하지 않아, 빈곤 유발의 구조적 요인을 무시 했다는 비판과 각국의 정책 여지를 제공했다는 긍정적 평가가 공존

- MDGs는 평화/안보, 거버넌스, 인권 문제를 다루지 않고 빈곤퇴치에 있어 개발, 경 제성장, 구조개혁이 갖는 역할 미반영의 한계 지적

- MDGs는 각국의 상이한 상황을 반영하지 않고, 적용 대상도 주로 개도국에 한정

- MDGs는 경제/사회/환경의 3대축 및 이슈간 상관관계를 반영하지 않고, 양적 (quantitative) 개선만 강조하여 질적(qualitative) 개선에 소홀

유엔기술지원팀은 $\mathrm{MDGs}$ 분석에 동의하며, $\mathrm{SDGs}$ 가 MDGs의 간결성 등 장점과 성과 를 계승하고, 한계점(획일성, 사회개발 치중, 질적 측면 소홀 등)을 극복해야 하며, 특 히 한국, 일본 등은 MDGs의 장점과 한계간 trade-off 관계를 고려해야 함을 언급

- MDGs 최대 강점인 간결성이 획일적 접근의 약점일수 있으나, 반대로 이행수단 결 여가 정책공간(policy space) 보장의 강점도 될수 있는 trade-off 관계를 균형적으 로 고려 필요 


\section{$\mathrm{SDG}$ 기본 원칙}

외훤국들은 RIO+20 결과문서 상의 SDGs 설정 주요 원칙을 재확인하였음

- 실행지향적이며, 간결하고, 소통이 용이하고, 숫자를 제한하고, 미래의 염원을 담아 야 함(action-oriented, concise, easy to commuicate, limited in number, aspirational)

- 보편적인 동시에 각 국의 상이한 현실을 감안할 것

- 빈곤퇴치를 overriding objective로 하며, post-2015 개발의제와 일관되게 통합 할 것

- 지속가능발전 경제/사회/환경 3 대 축을 균형있게 접근하고, 3 개 축간 상관관계를 반영할 것

○ 개도국들은 SDGs 설정에 있어 "공동의 차별화된 책임“을 강조하고, SDGs가 Agenda 21 , 요하네스버그 행동계획, $\mathrm{RIO}+20$ 결과문서 및 국제법에 부합하게 설정되어야함을 주로 언급하였음. 대부분의 국가는 SDGs 설정이 Post-2014 개발의제 논의가 Rio+20 후속 조치와 일관되게 추진되고, 시민사회를 비롯한 다양한 이해관계자의 의견과 전 문지식 반영 필요성을 강조

\section{$\mathrm{SDGs}$ 구조에 대한 의견}

○ (접근법) SDGs는 경제/사회/환경 지속가능성 제고 및 빈곤퇴치를 실현하는 변혁적 발 전(Transformational development)를 달성하기 위한 근본 원인을 다뤄야 하며, 이를 위해 single-issue based approach 보다는 integrated or systemic approach 필요

○ (EU 의견) 예비 의견임을 전제로, SDGs는 기초 생활수준(food, water, health 둥), 포용적 지속가능성장(지속가능한 에너지, 소비, 생산), 지속가능한 자원관리(해양, 산 림), 평등과 정의 확보(양성평등, 인권 등), 평화와 안보 등으로 구성 방식 소개

ㅇ (G77 의견) 다수 개도국은 SDGs가 체제변화적 발전목표가 되기 위해서는 국가내 및 국가간 불평등 문제, 금융위기를 초래한 국제경제시스템 개혁 등 구조적 이슈 및 기후 변화, 양성평등, 여권신장 등 cross-cutting 이슈를 다룰 것을 주장함 


\section{보편적이고 국별 상황에 맞는 $\mathrm{SDGs}$ 설정 방안}

○ 유엔은 개도국을 주요 고려 대상으로 삼았던 MDGs와 달리, SDGs는 모든 국가가 자 국의 우선 분야/역량/개발수준 등에 따라 개발 추진이 필요하며, 이를 위해 (1) 공동 목표를 설정하되 각국 상황에 맞도록 다양화한 세부 목표와 일정 부여 방식과 (2) 공동 목표를 설정하되, 각국이 선택할 수 있는 다수의 세부 목표와 지표를 제시하는 방식이 제안됨.

- 콜롬비아는 통일된 global dashboard를 마련하고, 각 국가가 자발적으로 자국 상황 에 맞는 세부목표/지표에 등록하면 SDGs 보편성과 개별성 동시 확보 가능하다는 의견 소개

\section{빈곤 퇴치와 SDGs}

애도국에서 하루 1.25 불 이하 인구 비율이 1990 년 $47 \%$ 에서 MDGs 목표 달성시한 보 다 5년 이른 2010년에 절반 이하 수준으로서 조기 달성 완료

- 다만, 아직 수십억 인구가 빈곤층이며, 겨우 극빈 수준을 넘은 인구가 위기에 취약 하며,

- 기후변화에 취약한 농어촌 지역 빈곤율이 도시 지역보다 높고, 빈곤층 내 여성/장애 인/아동/원주민/분쟁국가 주민의 빈곤율이 높은 경향 등 지역·국가 및 국내적으로 불균등 문제 상존

인곤은 단순 소득 문제가 아닌 원인과 효과가 다차원적인 바, 아래와 같은 다양한 노 력의 총체적 지원 필요

- 빈곤퇴치를 위해서는 친환경적이고 평등하고, 포용적인 경제성장

- 기초 서비스접근, 교육, 보건, 위기 대응, 사회적 보호 등을 포함한 강력한 국가정 책 추진

- 여성/장애인/농촌 주민 등 각 취약 계층에 대한 차별화된 접근

- 역진적 세금·보조금 및 거시경제정책 수정

- ICT 활용, 행정개선, 책임성 강화 등 효과적인 빈곤퇴치 거버넌스 구축

- 경제/사회/환경 등 지속가능발전 3 대축에 대한 통합적 접근

- 불평등, 불균등 분배 등 구조적 요소 등에 대책 
○ 빈곤퇴치에 관한 SDGs는 MDG 1 의 빈곤퇴치 목표로서 가졌던 간결성, 객관적 측정 성, 이해의 용이성 등 장점을 유지하면서, 다차원성을 감안한 빈곤 및 여타 SDGs에도 빈곤퇴치 관련 세부목표와 지표 반영 필요

- 다만, 하루 1.25 미불 빈곤선이 적절한 수준인지, 빈곤퇴치의 다차원성을 어느 수준 까지 개별 및 공통 성과에 반영할 지, 취약지역 및 취약층의 특수상황 및 필요를 어 떻게 반영할 지, 빈곤퇴치와 환경 관련 목표 통합을 국가 정책에서 어떻게 구현할 수 있을지 등 검토 필요

○ 대다수 회원국은 빈곤퇴치가 SDGs의 전반을 포괄하는 목표(overarching objective) 이며 지속가능 발전과 빈곤퇴치는 동전의 양면과 같이 밀접한 연관성에도 동감함. 특 히 빈곤퇴치는 다차원적이므로 포괄적 접근법(holistic approach)의 필요성에 동의하 며, 추후 빈곤퇴치를 SDGs에서 단일 분야로 다룰지, 범 분야로 다룰지 논의 예정1)

○ 또한, 다수의 회원국은 빈곤퇴치에 있어 MDGs의 유용성 및 성과를 평가 하고, $\mathrm{MDG}$ 가 미달성한 부분이 SDGs 구상의 출발점이 되어야 하며, SDGs는 구체 이행수단 및 불평등 등 구조적 원인을 담은 인간중심적 접근(people-centered approach)를 해야 한다고 강조

- 목표 달성 자체 보다, 목표 달성에 따른 행복과 삶의 질 개선에 의미 있는 결과가 되도록 질적 평가가 병행되어야 할 필요성 제기

\section{3) SDGs와 녹색 성장}

Post-MDGs 개발 의제 논의에서 SDGs는 Post-2015 프레임워크 형성과정에서 여러 아젠 다들과 경쟁되어 논의되는 것이 아니라, 다른 개발 아젠다들과 함께 글로벌 개발목표로 통합 반영되어야 한다고 보고 있다. (UNDP, 2011) 이는 Post-MDGs와 Sustainable Development 는 서로 양립하지 않으며 상호 보완적이어야 하며, 총체적 개발 패러다임인 Sustainable Development이 MDGs의 프레임워크와 구체 목표 설정시 적절히 구현되어야 할 필요성에 대 해 국제 사회가 공감하고 있음을 의미한다.

1) 옥스퍼드빈곤인간개발이니셔티브(OPHI)의 Alkire 소장은 빈곤의 다차원성을 반영한 복합지표로서 영양섭취, 교육 수준, 보건 등 빈곤 관련 요소를 가중평균한 Multidimensional Poverty Index(MPI)를 제시하며, 다차원적 빈곤 수준이 용이 하며, 구성 요소의 필요 및 우선순위에 따라 변화시킬수 있다는 장점을 소개하였다. 
Sustainable Development는 단순히 “환경을 고려한 개발”이라는 부분적이며 단편적인 고 려 요소가 아니라, "경제, 사회, 환경의 세 개의 축이 통합적으로 고려된 개발" 패러다임을 의 미한다. 따라서 현재 논의되는 MDGs의 다양한 의제에 대한 분절적 고려가 아닌, Cross-cutting적으로 모든 의제에 고려하여야 하며, 특히 현재 기후변화와 환경 오염, 자원 고갈 등 환 경적 위험과 경제 위기, 빈곤 퇴치 등의 개발 문제와의 높은 상호 연관성을 고려할 때 포괄적 이고 통합적인 접근법이 의제 개발 과정에서 요구 된다.

Post-MDGs 개발 의제는 빈곤퇴치 등 기존 MDGs의 노력들을 계속 계승 발전시켜 나가야 하는 원칙은 유지하되, 기존의 틀에 많은 수정 보완이 필요한 시점이다. 예를 들어 하루 2 달러 내에 생활하는 사람 대부분은 중소득국가(middle income country)에 살고 있으며, 이는 급격 한 도시화와 산업화로 사회적 소외와 환경적 외부효과가 발생함에 따라, 경제, 환경, 사회적 지속가능성에 모두 문제가 되고 있는 것이다. 특히 환경 문제와 자원 고갈은 지구적 생존뿐 아 니라, 과거 역사에서 보듯 경제 성장과 정치적 분쟁을 야기함으로써 인간 개발의 최대 위험 요 소를 조장하고 있다. (GGGI, 2013)

과거 1992년 세계지속가능정상회의에서 발족한 Sustainable Development의 이념은 지난 25년간 정치적 구호와 모호한 개념으로 실질적 기여가 낮았다는 평가를 받았다면, 최근 녹색 성장(Green Growth)의 대두는 Sustainable Development의 실제 구현을 위한 전략으로써 진 일보 했다는 평가를 받고 있다. 녹색 성장은 환경과 자원 위기 해결 뿐 아니라, 기존의 경제 성장 모델의 근본적 대안을 제시함으로써, 지속가능한 개발의 환경과 경제의 상생적 통합 문 제를 해결하기 위한 경제 패러다임이다.

녹색 성장은 기존의 국제 사회나 시민사회에 의해 주도되는 하향식(top-down)의, 개념적이 고(norm-driven), 환경정책적(environmental policy) 의제가 아니라, 개발도상국이나 신흥국 에 의한 상향식(bottom-up)의 실천 지향적이고(action-oriented), 경제 정책적(economic policy) 의제라고 할수 있다. 많은 개도국들은 현 경제개발 전략을 녹색화 하고, 과거 선진 경제 권의 산업화와 경제 개발 중심의 Brown 경제 모델을 뛰어 넘어야 하는 시점에 와 있으며, 향후 10 여년간의 변화의 성공 여부가 향후 40-50년간의 미래를 좌우 하게 될 것이다. (GGGI, 2013)

결론적으로 Post-2015 아젠다 논의는 SDGs를 통해 개발도상국의 지속가능한 개발목표 달 성의 중장기적 목적 달성에 기여하고, 녹색 성장을 통한 경제와 환경의 통합적 고려를 위한 새 로운 경제 모델을 제시함으로써, MDGs의 주요 목표인 빈곤 퇴치와 각 사회경제적 개발 목표 
해결 뿐 아니라, 현 기후변화와 자원 고갈에 대처함으로써 전 인류의 생존 기반인 지구를 후세 대에게 온전히 물려줄 수 있는 전략으로써 최우선 고려되어야 할 것이다.

〈표 1〉녹색 성장 VS 지속가능한 개발

○ 녹색성장은 개도국의 중장기적인 지속가능한 개발을 달성하기 위한 강력한 도구이다.

- 개도국은 빈곤퇴치, 복리증진, 삶의 질 향상이 주요 국가 목표이며, 이는 지속 가능한 자연자원 활용이 경제 성장에 중요함을 인식하고, 지속가능한 생산과 소비의 촉진이 필요하다

옥색성장은 새로운 경제 패러다임으로, 전 섹터에 걸쳐 통합적으로 고려되어야 한다

- 녹색성장은 경제 위기와 물, 에너지 등 자원 부족, 기후변화와 생태계 위기에 대응하기 위하여, 전 경제 영역(sector-wide approach)에 걸쳐 기존의 자원 착취와 환경 오염 등을 발생하는 경제 성장 방식(Brown Economy)이 아닌 환경과 자원, 경제를 동시에 고려한 새로운 경제 성장 방식(Green Economy)이다.

○ 녹색성장은 지속가능한 개발의 한 축인 사회적 지속가능성(Social substantiality)에 대한 고려가 필요하다.

- 녹색성장은 경제 개발과 환경적 고려를 중심으로 발전된 경제 성장이론으로서, 정책 효과에 따른 형평성(equity) 문제, 빈곤층 및 사회 약자층 배려, 지역 공동체 강조, 삶의 질 향상 등을 위한 정책적 보완이 요구된다.

\section{3. 녹색성장과 개도국}

현재 녹색성장의 개념이 지나치게 신재생에너지, 청정기술 등 선진국 측면의 신성장산업이 나 선진기술 위주로 논의되면서, 개도국 차원에서 비난을 받고 있으므로, 향후 개도국 관점에 서의 녹색성장에 대한 접근법이 요구된다. 이를 위해서는 개도국이 선진국과 개발 단계 및 경 제 구조가 다르고, 개도국만의 특성과 필요를 이해해야 한다.

개도국은 기후변화로 인한 높은 취약성과 낮은 대응(Resilience) 능력, 전통적 경제 성장모 델로 인한 환경 오염, 자원고갈 등 문제 직면, 환경 및 자원에 대한 높은 경제 의존도로 인한 안정성 저해(instability), MDGs 달성을 위한 기후변화 및 환경 문제가 주요 저해요소로 작용 
하는 등 전반적으로 사회경제 전반에 개발의 지속 가능성 측면에서 많은 문제점을 갖고 있다. 따라서 향후 개도국에 적합한 녹색성장 모델 수립 및 지원을 위해서는 이러한 사항에 대해 우 선적 이해가 선행되어야 할 것이며, 이에 대해 아래에서 상술하고자 한다.

첫째, 개도국은 환경 및 자연자원(natural asset)에 대한 높은 경제적 의존도를 갖고 있다. 선진국과 개도국의 국부 창출 자본의 기여도를 보면, 2005 년 기준으로 $\mathrm{LIC}$ 국가의 $36 \%$, $\mathrm{UMIC}$ 국가의 $17 \%, \mathrm{OECD}$ 국가 $2 \%$ 로서 빈국일수록 자연 의존형 산업 비중이 높다(World Bank, 2005) 개도국의 농업, 목축, 자연 자원 등 1차 산업에 의존도가 높아, 기후변화에 취약 한 산업구조를 가지고 있다. 개도국 주민의 $50 \%$ 이상이 온도 변화와 강수량, 염수에 의해 큰 영향을 받는 농업에 생계를 의존해 살아가고 있다. 이로 인해 무분별한 자원 착취와 산림 벌 채, 기후변화로 인한 토지 이용 변화 등은 궁극적으로 개도국의 가장 빈곤한 계층에 직접적인 타격을 줄 수 있다.

〈표 2〉소득별 부의 창출 자본 비율 2005

\begin{tabular}{c|c|c|c|} 
& intangible capital & produced capital & natural capital \\
\hline Low Income & $50 \%$ & $14 \%$ & $36 \%$ \\
\hline Lower Middle Income & $50 \%$ & $24 \%$ & $25 \%$ \\
\hline Upper Middle Income & $67 \%$ & $17 \%$ & $17 \%$ \\
\hline High Income : OECD & $81 \%$ & $17 \%$ & $2 \%$ \\
\hline
\end{tabular}

Source: World Bank(2011)

\section{〈그림 1〉저소득국의 부의 창출 자본 〈그림 2〉 저소득국 자연자본 구성 요소}

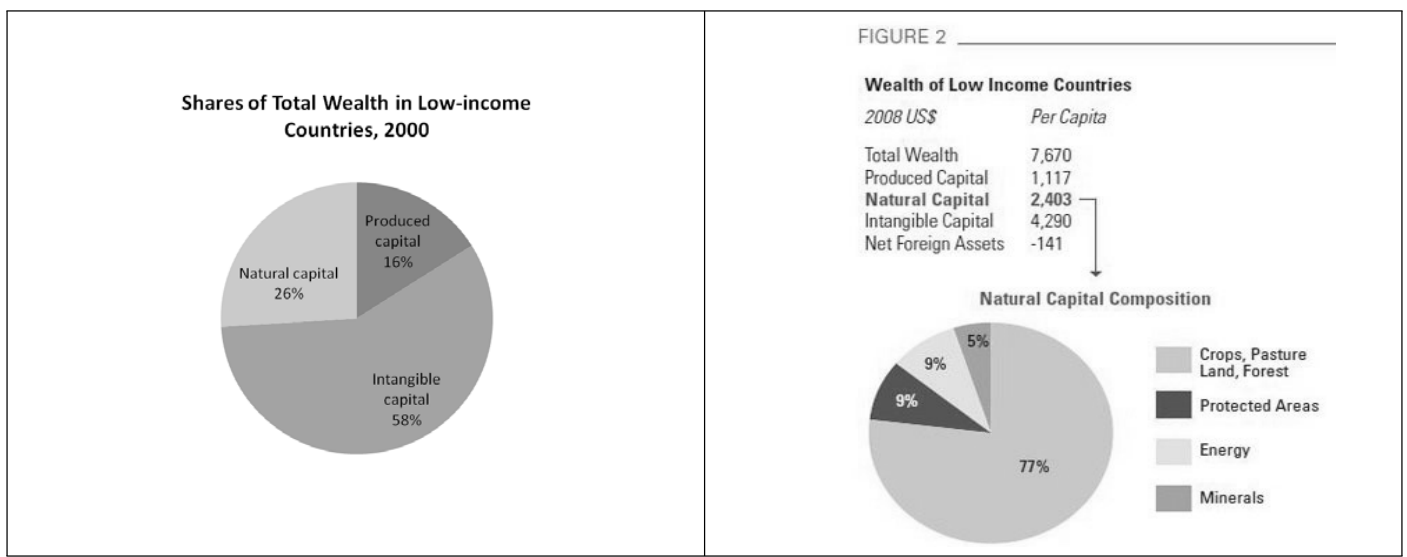

Shares of Total Wealth in Low-income Countries, 2000 (Source: World Bank, 2006) http : //go.worldbank.org/R0F611S5F0

(Source : World Bank 홈페이지) 
둘째, 개도국은 기후변화로 인한 취약성이 급격히 증가하고 있다. 개도국들은 경제개발 뿐 아니라, 경제개발을 저해할 수 있는 기후변화 관련 재난 재해의 리스크에 노출되어 있으며, 이 에 대한 방지책 마련이 시급하다. 기상재해 사망자 증가, 곡물 생산량 감소, 전염성 질병 증 가, 기후 난민 발생, 물 부족 확대 및 자원 경쟁 등이 대표적인 예다. 기후변화 취약성에 따른 분포도를 보면 개도국에 집중적으로 분포하고 있다. 1960-2006년 동안 자연재해에 의한 사상 자 수가 중고소득 국가에 비해 저소득 국가가 월등히 높은 비율을 차지한다. 앞으로도 사망자 의 $90 \%$ 이상이 개발도상국에서 발생할 것으로 전망된다.

특히, 개발도상국은 태풍, 사막화, 해수면 상승의 위협 받는 지역에 다수 위치해있고, 자연 자원 의존형 경제구조로서 자연재해로 인한 인명 및 시설 피해, 자원 고갈 등에 대응하는 제도 적 역량 및 인프라가 부족한 상황이다. 최근 2012년 태국 방콕에서의 홍수피해는 1997-1998 의 아시아 금융 위기 이후 국가의 가장 큰 규모인 GDP규모의 $9 \%$ (460억 달러의 피해)에 해당 하는 규모로 이는 향후 50 여년간 기후변화가 급속히 진행될 것으로 예측되는 상황에서 선진국 에 비해 자연 재해 대응 역량이 부족한 개도국이 입는 막대한 경제적 피해에 대한 경고적 메시 지라고 할 수 있다.

\section{〈그림 3〉 소득 수준별 사망자 피해}

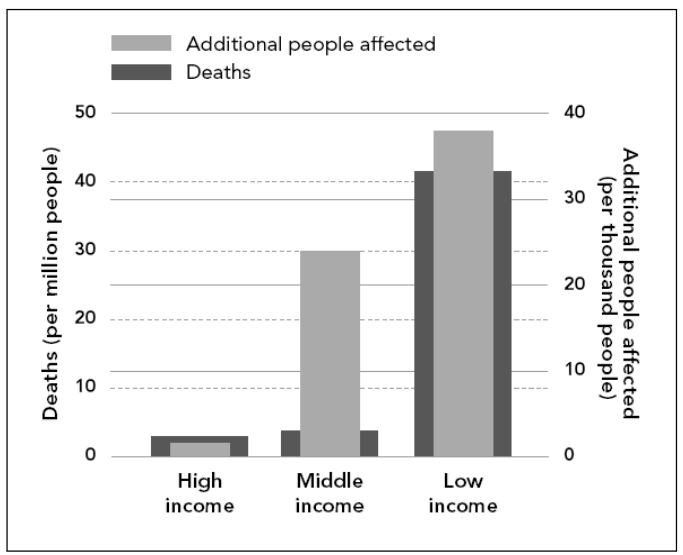

〈그림 4〉기후변화 취약국 분포

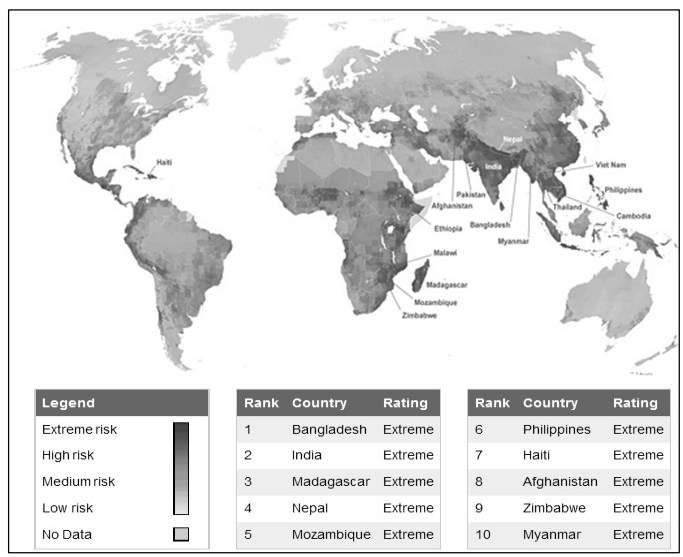

(Source : Maplecroft, 2011)

또한, 남태평양도서국인 투발루는 해수면 상승으로 국가 전체가 바다에 잠겨 사라지고 있으 며, 유엔난민기구(UNHCR)는 기후변화 현상으로 인해 고향을 떠난 세계 난민 수가 현재 2 억 5 천만 명에서 향후 50 년 내에 10 억 명으로 증가할 것으로 예상하고 있다. Climate Vulnerability Forum(2012) 보고서에서는 2030년경에는 기후변화 피해와 탄소 경제로 인한 
문제가 전 세계 $\mathrm{GDP}$ 의 $3 \%$ 를 넘을 것으로 예상하면서, 만일 별도 기후변화 대책이 없다면, 2010 년 현재 GDP의 $1.6 \%$ 피해가 생기고, GDP의 $0.5 \%$ 만 투자하면, 즉 피해 예상액의 $1 / 3$ 만 투자하면 예방이 가능하다고 전망 하였다.

셋째, 기후변화로 인한 $\mathrm{MDG}$ 악영향이 증가하고 있다. 기후변화 문제는 범 분야 이슈로서 개발 전반에 걸쳐 중요성이 증대 되고 있으며, 새천년개발목표(MDGs) 전반에 미치는 영향이 증대되어 개발목표 달성에 있어 최대 저해 요소로 대두되고 있다. 그간 기후변화에 취약한 빈 곤계층이 기후변화에 노출되면 더욱 빈곤해지고 MDGs를 이루려는 노력에 문제가 될 수 있다 고 지적되어 왔다. MDGs 목표 1 8 전반에 대한 기후변화 문제의 직간접 영향에 대해 표 3 은 주요 사례를 설명하고 있다.

\section{〈표 3〉MDGs와 기후변화의 연관성}

\begin{tabular}{|c|c|}
\hline MDGs & 기후변화와의 연계성 예시 \\
\hline 절대빈곤 몿표 1 & $\begin{array}{l}\text {. 빈곤층의 보건, 수자원의 접근성, 기반시설 등 일상생활의 자산 악화 야기 } \\
\text {.기후변화로 인한 자연자원, 기반시설, 노동 생산성의 변화로 인한 소득의 감소 } \\
\text {.지역(특히 아프리카)의 식량 안보 위협 }\end{array}$ \\
\hline $\begin{array}{c}\text { 목표2 } \\
\text { 보편적 초등교육 달성 }\end{array}$ & . 기후변화의 영향(자연재해, 가뭄, 잦은 이주)은 어린이들의 교육 기회를 감소시킴 \\
\hline $\begin{array}{l}\text { 목표 } 3 \\
\text { 남녀평등 및 여성능력 } \\
\text { 고양 }\end{array}$ & $\begin{array}{l}\text {.자연자원 및 농업생산성의 감소는 여성들의 건강에 부담을 주며, 의사결정과정이나 소 } \\
\text { 득 생산활동에 참여할 수 있는 시간을 줄임 } \\
\text {.기후변화 관련 재해는 여성 가장 가구에 더 심각한 영향 }\end{array}$ \\
\hline $\begin{array}{c}\quad \text { 목표4 } \\
\text { 아동사망률 맘소 } \\
\text { 목표5 } \\
\text { 모성보건 증진 } \\
\text { 목표6 } \\
\text { 각종질병 퇴치 }\end{array}$ & $\begin{array}{l}\text { 혹서 관련 사망률 및 유병률 증가 } \\
\text {.기후변화에 따른 질병 (말라리아, 뎅기열) 및 물, 음식, 접촉에 의한 질병 취약성 증가 } \\
\text { (콜레라, 설사병) : 어린이들과 임산부들 특히 민감 } \\
\text {. 특히 아프리카 사하라 사막 이남 지역의 식수의 양 및 질 저하와 영양실조 악화 유발 }\end{array}$ \\
\hline $\begin{array}{c}\text { 목표7 } \\
\text { 지속가능한 환경보전 }\end{array}$ & $\begin{array}{l}\text { 자연자원 및 생태계의 질과 생산성을 변형하고, 이러한 변화는 생물다양성의 감소와 환 } \\
\text { 경 황폐화를 가져옴 }\end{array}$ \\
\hline $\begin{array}{c}\text { 목표8 } \\
\text { 범지구적 파트너십 구축 }\end{array}$ & $\begin{array}{l}\text { 기후변화는 전 지구적 이슈로서, 특히 개발도상국이 기후변화의 악영향에 적응하는 것 } \\
\text { 을 돕기 위한 전 지구적 협력 필요 }\end{array}$ \\
\hline
\end{tabular}

개발도상국이 경제 성장과 환경 부하의 비연동 발전(Decoupling)을 위해서는 자원 고갈, 환 경 오염, 기후 위협을 양산하는 기존의 경제 성장 모델을 벗어나서, 기후 변화에 적응, 자원 순환 및 친환경적 경제 개발이 상생하는 녹색 경제 구현을 위한 녹색성장 모델이 시급하다. 
과거 환경쿠즈네츠곡선(Environmental Kuznets Curve/EKC)에 의하면 개발도상국의 경우 경제가 성장할수록 환경이 오염되다가, 소득이 일정수준 넘어서면 축적된 자본으로 환경 보전 과 복원을 통해 오히려 오염이 줄어드는 역 U자 곡선으로 설명해왔다. 그러나 앞으로는 개발 도상국의 기존의 국가 사회경제 개발 계획의 의사 결정시 환경 및 기후변화 요소를 통합 개발 하는 녹색 성장전략 개발을 통해서 이러한 쿠즈네츠 가설을 극복 할 수 있으며, 따라서 전 지 구적 생존과 후세대의 복지를 위한 대안적 경제 모델 개발에 전세계가 고민해야 한다.

개도국은 기존의 경제개발계획의 녹색화를 통한 지속가능한 경제 성장 모델 수립이 절실히 필요한 상황이다. 향후 UN 기후변화협약은 2020년부터는 개발도상국도 온실가스 저감 대상 국가로 포함할 계획이며, 이는 기존의 경제 모델의 개혁을 위한 행동을 지금부터 준비하지 않으면, 경제 성장의 걸림돌로 작용하게 될 것이고, 이를 수정하기 위해서는 더 많은 비용을 요구하게 될 것임을 보여준다. 따라서, 선진국은 개발도상국의 녹색 성장 지원을 위해 ODA 재원 및 민간 투자 등 지원을 확대함으로써, 개발도상국의 경제 발전 초기 단계에서 이미 밝 혀진 과거의 비환경적인 낡은 경제모델에서 지속가능한 경제 모델로의 우회(By-passing)가 가능하다.

〈그림 5〉 환경쿠즈네츠곡선

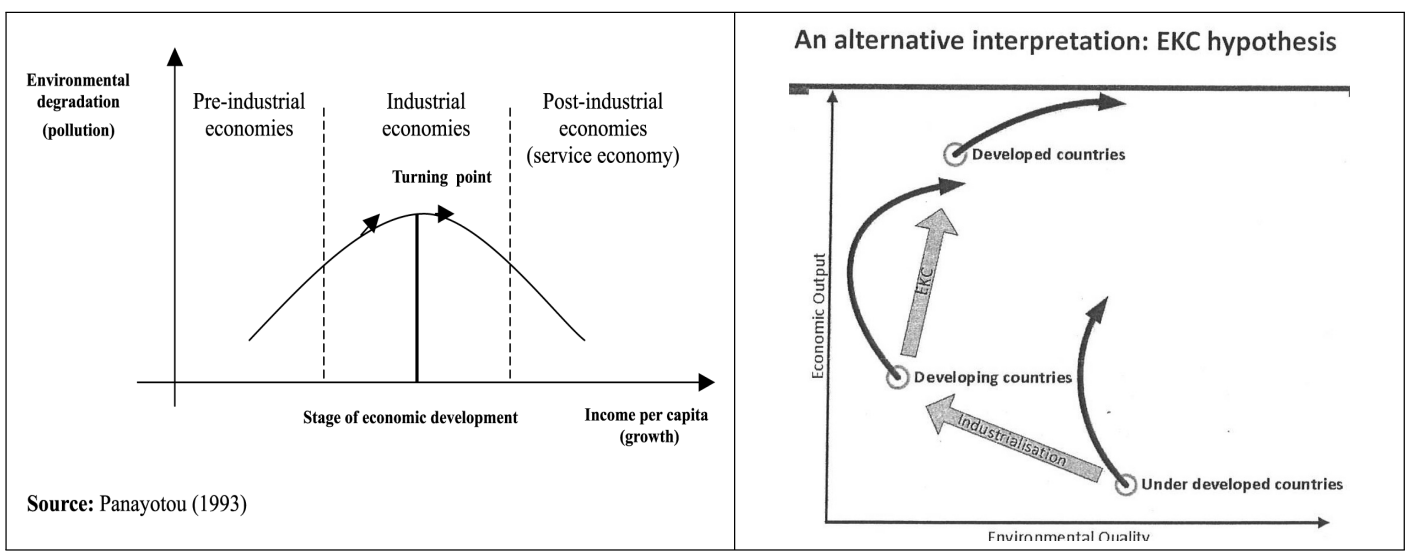

(Source : GGGI 발표자료, 2012)
〈그림 6〉 저개발국의 녹색성장 전략 모델

nuirnnmentat

. 


\section{〈표 4〉 KOICA 베트남 녹색성장전략 마스터플랜 수립사업}

베트남은 ‘86년 도이모이 이후 년 6-8\% 이상의 높은 경제성장률을 통해 양적성장을 달성하였으나, 제조업, 중공업 등 화석연료 중심의 자원 소비형 경제구조와 환경오염 심화, 기후변화에 따른 해수면 상승 피해 등에 따라 기존의 경제 개발 모델의 한계에 도달하였음

$\square$ 이에 베트남 정부는 환경 및 기후변화 대응을 고려한 경제 성장 패러다임의 전환 필요성을 자각하고, 주재국 기획투자부(MPI)는 '베트남 녹색성장전략(Vietnam Green Growth Strategy, VGGS)'계획안을 '11년 말부터 추진, '12년 6월 최종안을 주재국 총리실에 제출하였음

$\square$ 베트남 MPI 주관 하에, 재무부, 건설부, 산업통상부 등 각 행정부처의 참여를 기본으로 베트남 개발전략연구소와 경제연구소의 자문 등을 통해 녹색성장 로드맵을 구축하였 음. 베트남 녹색성장전략은 온실가스 배출 감소를 통한 지속가능한 경제 개발의 비전으로 3 개의 주요 목표와 해당 목표를 달성하기 위한 3개의 주요 과제, 그리고 각 과제를 달성하기 위한 대안들이 제시되어 있음

$\square$ '12년 8월 24일 베트남의 MPI가 방한하여 KOICA와 함께 '베트남 녹색성장 마스터플랜 수립사업'에 관한 업무협조약정(MOU)를 체결하였으며, KOICA는 양국간 협력사업으 로 선정하여 2013-2014년 2년간 200만불 규모로 베트남 정부를 지원할 계획임.

$\square$ 베트남 녹색성장 마스터플랜은 우리나라의 ‘녹색성장 5 개년 계획' 모델을 기초로, 국별 발전단계, 기술 수준 등을 고려하여 베트남 실정에 맞도록 조정하고, 주재국 핵심 경제개발 계획인 ‘SEDP(Social Economic Development Plan) 2011-2015’와 연계 지원함으로써 주재국의 개발 목표에 동 사업을 일치토록 사업 방향을 설정함.

베트남의 녹색성장을 위한 마스터플랜 수립과 함께 전담기구 설립, 전문가 파견, 초청 연수 등을 진행할 예정임. 이번 MOU는 베트남 정부가 국가개발 전략의 하나로 지속가능한 개발을 위한 국가 녹색성장 전략을 마련하여 한국에 녹색성장 전략과 계획 경험에 대한 지원을 요청해 왔다는 점이 주목할 만함.

\section{4. 녹색 ODA 개념 및 분류}

\section{1) 녹색 ODA 개념}

“녹색 $\mathrm{ODA}$ ”라는 용어는 아직 전 세계적으로 명확한 범주나 개념적 정의가 정립되어 있지 않으며, 주요 공여국들은 주로 “환경”이나 “기후변화 ODA” 용어를 주로 사용하고 있다. 현재 
는 OECD의 리오 마커(Rio Marker)*2) 등 관련 섹터의 통계를 집계하기 위한 노력이 이어지 고 있다. 녹색 $\mathrm{ODA}$ 에 대한 개념 정립이 어려운 이유는 녹색 ODA의 개념이 여러 분야에 포괄 적으로 적용될 수 있기 때문이며, 주요 국제기구들 또한 다양한 영역을 녹색의 범위에 포함시 키고 있기 때문이다.

한편, 우리 나라가 사용하고 있는 2012년 5월 녹색성장위원회에 의해 녹색 ODA는 아래와 같이 정의하고 있다. ${ }^{3)}$

와석연료의 사용을 축소하고 환경 친화적인 기술과 산업을 경제성장의 동력으로 육성 함으로써, 지속가능한 발전 도모

○ 에너지·자원 이용의 효율성을 높이고 자원순환을 촉진하는 경제·사회구조로 전환

기타 $\mathrm{OECD}$ 환경마커 혹은 리오마커 기준을 충족하는 활동

〈그림 7〉 UNEP 및 OECD 녹색사업 분류

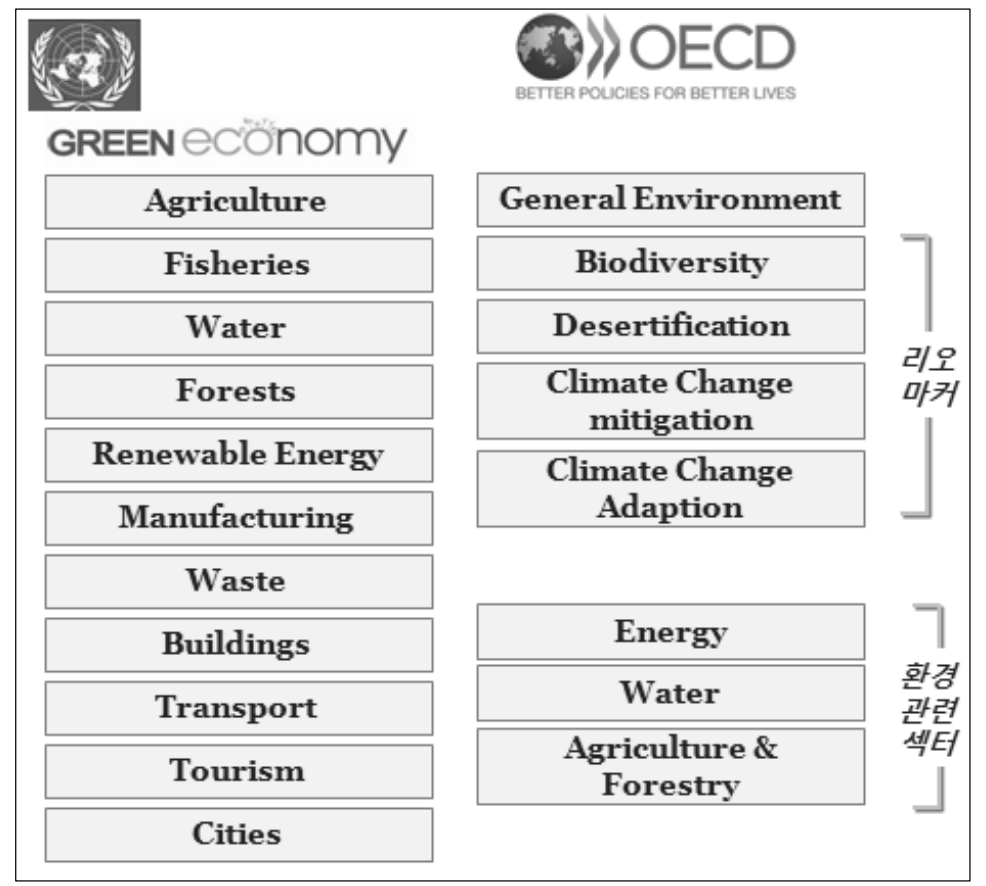

2) Rio Marker : 3 대 환경협약(기후변화, 사막화방지, 생물다양성) 관련 개도국에 대한 ODA 제공 내역을 DAC 회원국이 CRS(Creditor Reporting System)로 통보

3) 녹색성장위원회, `글로벌 녹색성장 확산을 위한 녹색 ODA 발전방안,, 2012.5월 
〈그림 8〉 환경마커 및 리오마커 개념

\begin{tabular}{|c|c|}
\hline 구분 & 개념 \\
\hline $\begin{array}{l}\text { 환경 } \\
\text { 마커 }\end{array}$ & $\begin{array}{l}\diamond \text { 환경에 대한 원조 } \\
\text { (1) 수원국, 지역 혹은 목표 집단의 물리적 - 생물학적 환경 개선을 가져오는 활동 } \\
\text { (2) 제도 구축 및 역량 개발을 통해, 환경적 고려를 개발 목표에 통합시키는 구체적인 활동 }\end{array}$ \\
\hline $\begin{array}{l}\text { 리오 } \\
\text { 마커 }\end{array}$ & $\begin{array}{l}\diamond \text { 생물 다양성 관련 원조 } \\
\text { (1) 생물다양성 보존, (2) 생물다양성 구성요소의 지속가능한 활용, (3)유전자원 활용 혜택의 } \\
\text { 공정하고 형평성 있는 분배 촉진 } \\
\diamond \text { 기후변화 관련 원조(완화, 적응) } \\
\text { (1) 기후변화 완화 : 온실가스배출을 감축 혹은 제한하는 활동 } \\
\text { (2) 기후변화 적응 : 적응·회복 능력을 유지, 증대하는 활동 } \\
\diamond \text { 사막화 관련 원조 } \\
\text { 건조, 반건조 및 반건조 습윤지역의 사막화를방지하거나, 가뭄으로 인한 영향을 완화하는 } \\
\text { 활동 }\end{array}$ \\
\hline
\end{tabular}

최근 국제사회에서 2012년 RIO+20에서 “녹색 경제” 개념이 부각되면서 경제 분야 전반의 친환경적 노력을 강조 하고 있다. UNEP는 녹색경제(Green Economy) 및 OECD는 녹색성장 (Green Growth) 등을 표방하면서 지속가능한 개발의 구체적 이행 전략으로 정책개발 및 연 구, 지식 네트워크 등에 최근 적극 참여하고 있다.

\section{2) $\mathrm{KOICA}$ 녹색 ODA 분류}

녹색 $\mathrm{ODA}$ 대상 범위는 상기 녹색 $\mathrm{ODA}$ 기준에 해당하는 $\mathrm{OECD}$ 환경 및 리우마커 등 정책 마커의 정의를 준용하여 $\mathrm{KOICA}$ 차원의 녹색 $\mathrm{ODA}$ 사업 대상 범위, 기준을 아래와 같이 설정 하였다.

1) 일반 환경 $\mathrm{ODA}$ : 환경 오염방지, 보호, 관리 등 환경 문제 개선 및 해결

2) 기후변화 $\mathrm{ODA}$ : 기후변화 문제 대응을 위한 기후변화 적응 및 완화

3) 농림수산 $\mathrm{ODA}$ : 자연환경을 보전하고, 이를 친환경적으로 활용하는 산업 지원

4) 개발녹색화 ODA : 환경적 지속가능성 확보를 위한 포함하는 기타 지원

상기 기준에 따라 주요 개념에 따라, 환경, 물, 저탄소에너지, 농림수산, 기타 등 주요 녹색 $\mathrm{ODA}$ 섹터별 $\mathrm{CRS}$ 코드와 연동되는 분류 기준 및 주요 사업을 아래와 같이 제시함으로써, 향 후 녹색 $\mathrm{ODA}$ 실적 통계, 관련 정책 개발 등에 활용해 나갈 예정이다. 
〈표 5〉 KOICA 녹색 ODA 분류 및 해당 사업

\begin{tabular}{|c|c|c|}
\hline 분야 & 분류 (CRS코드 기준) & 해당사업 \\
\hline 환경 & $\begin{array}{l}\text { - 환경 정책 및 관리 } \\
\text { - 환경 교육 및 연구 } \\
\text { - 생물권 보호 } \\
\text { - 생물종 다양성 } \\
\text { - 폐기물 관리 및 처리 등 }\end{array}$ & $\begin{array}{l}\text { - 환경오염 개선/방지 마스터플랜 수립 } \\
\text { - 지역주민 대상 환경교육 센터 구축 } \\
\text { - 생물다양성 보전 역량강화 } \\
\text { - 폐기물 매립장 건립 실시설계 } \\
\text { - 자원순환형 생태공원 기반구축 }\end{array}$ \\
\hline 물 & $\begin{array}{l}\text { - 수자원 정책 및 관리 } \\
\text { - 기초 식수 공급 및 위생 } \\
\text { - 상하수도 시설 } \\
\text { - 하천 유역 개발 } \\
\text { - 홍수 방지 및 제어 등 }\end{array}$ & $\begin{array}{l}\text { - 통합수자원관리 GIS 구축 } \\
\text { - 지하수 개발 및 식수개발 } \\
\text { - 지역 식수위생환경 개선 } \\
\text { - 배수시설 마스터플랜 및 실시설계 } \\
\text { - 상수도 시스템 구축 타당성조사 } \\
\text { - 하천유역 홍수 예경보 시스템 구축 }\end{array}$ \\
\hline $\begin{array}{l}\text { 저탄소 } \\
\text { 에너지 }\end{array}$ & $\begin{array}{l}\text { - 에너지 정책 및 관리 } \\
\text { • 발전 및 재생에너지 } \\
\text { - 에너지 교육 및 연구 } \\
\text { - 수력발전, 태양 에너지, 풍력, } \\
\text { 해양에너지, 바이오매스 등 } \\
\text { * 신재생에너지 관련 }\end{array}$ & $\begin{array}{l}\text { - 에너지 분야 역량강화 } \\
\text { - 배전 손실감소 및 자동화 시스템 구축 } \\
\text { - 태양광 효율향상 연구시설 구축 } \\
\text { - 국가 재생에너지 마스터플랜 수립 } \\
\text { - 태양광 발전소 건립 } \\
\text { - 폐잔재를 활용한 바이오에너지 생산 }\end{array}$ \\
\hline 농림수산 & $\begin{array}{l}\text { - 농림수산 정책 및 관리 } \\
\text { - 농림수산 개발 } \\
\text { - 농업용 수자원 } \\
\text { - 식량 생산 등 }\end{array}$ & $\begin{array}{l}\text { - 친환경 농업 기술 및 산업기반 지원 } \\
\text { - 저수용 댐 및 관개수로 건설 } \\
\text { - 해양 양식장센터 건립 } \\
\text { - 농작물 생산성 향상 역량강화 } \\
\text { - 기후변화적응 시범온실 지원 } \\
\text { - 산림보전 및 관리 역량강화 }\end{array}$ \\
\hline 기타 & $\begin{array}{l}\text { - 일반 ODA의 녹색화 } \\
\text { - 기타 관련 분야 등 } \\
\text { (녹색성장, 말라리아 퇴치, } \\
\text { 재난방지 및 대비 등) }\end{array}$ & $\begin{array}{l}\text { - 국가 녹색성장 마스터플랜 수립 } \\
\text { - 기후변화에 따른 매개모기질병 방지 } \\
\text { - 기상위성 데이터수신분석 시스템개발 } \\
\text { - 기후변화적응 지역 GIS 구축 }\end{array}$ \\
\hline
\end{tabular}




\section{5. 국제 사회 및 한국의 녹색 ODA 현황}

\section{1) 국제 사회의 녹색 ODA}

기후변화 및 녹색성장 관련 이슈는 전 지구적인 문제로서 한 국가의 힘으로 달성하기는 어 려우므로 국가 간 협력이 필요하다. 특히 2008년 기후변화당사국총회 이후 국제 기구 및 선진 국들은 개발도상국의 기후변화 및 환경문제, 지속가능한 개발을 지원하기 위한 대규모 신규 추가 재원(new and additional)을 공약하고, 기후변화 대응에 특화된 각종 이니셔티브 사업 을 본격적으로 실시하고 있다.

〈표 6〉 주요 공여국의 기후변화기금(2008-2012)

\begin{tabular}{c|c|c|c}
\hline 국가 & 기금 & 규모(백만불) & 기간 \\
\hline 일본 & Cool Earth Partnership & 10,000 & '08-'12 \\
\hline 영국 & Environmental Transformation Fund & 1,182 & '08-'10 \\
\hline 독일 & International Climate Initiative & 764 & '08-'12 \\
\hline 호주 & International Foreign Carbon Initiative & 132 & '07-'11 \\
\hline 스페인 & UNDP-Spain & 114 & '07-'10 \\
\hline 노르웨이 & Climate and Forest Initiative & 연간 500 & '08- \\
\hline 한국 & East Asia Climate Partership & 20 & '08-'12 \\
\hline
\end{tabular}

2009년에 코펜하겐 정상회의 합의에 따라 선진국이 2010년 2012년 매년 100억달러씩 3년 간 300 억불의 Fast Start Finance(FSF) 단기 재원의 지원 기간을 약속하였으며, 당사국총회 제 17 차 더반회의 및 18 차 카타르 결과로, 2013년 이후부터는 사무국이 한국에 유치된 녹색기 후기금(GCF)을 통해 2020년까지 연간 1천억달러의 장기재원(long term finance) 마련을 조 달하여 개도국의 기후변화 적응과 완화에 지원키로 약속 하였다. ${ }^{4)}$

4) '2013 2020년까지 매년 1000억달러'라는 문구에 대한 해석을 놓고 논란이 많은 상황이다. 개도국들은 2013년부터 매년 1000 억달러씩 8년간 조성해 총 8000 억달러를 조성한다는 의미로 해석하고 있다. 반면 선진국들은 현재 100 억달러 수준 에서 매년 단계적으로 올려 2020년부터 매년 1000억불 수준으로 간다는 의미로 풀이하고 있다. 제18차 UNFCCC 당사 국 총회에서는 일부 개도국은 2015년까지 600억달러 지원을 문서로 약속하라고 요구했으나, 선진국들은 '2013 2015 년은 최소한 긴급자금(fast start finance) 기간의 평균 이상을 지원하도록 노력한다'는 문구를 결정문에 포함하는 수준 에 그쳤다 
〈표 7〉 개도국의 기후변화 대응 지원을 위한 국제사회의 주요 기금

\begin{tabular}{|c|c|}
\hline 기금의 목적 & 기금 종류 \\
\hline 기후변화 완화 & $\begin{array}{l}\text { - 탄소기금(Carbon Funds) } \\
\text { - 산림탄소파트너십기구(Forest Carbon Partnership Facility) } \\
\text { - 탄소파트너십기구(Carbon Partnership Facility) }\end{array}$ \\
\hline 기후변화 적응 & $\begin{array}{l}\text { - 최빈국기금(LDC Funds) } \\
\text { - 적응기금(Adaptation Fund) } \\
\text { - 지구재해감소및복원기구 } \\
\text { (Global Facility for Disaster Reduction and Recovery) }\end{array}$ \\
\hline $\begin{array}{c}\text { 기후변화 완화 및 } \\
\text { 적응 }\end{array}$ & $\begin{array}{l}\text { - 지구환경금융(Global Environment Facility) } \\
\text { • 기후투자기금(Climate Investment Funds) } \\
\text { • 특별기후변화기금(Special Climate Change Fund) }\end{array}$ \\
\hline
\end{tabular}

자료: World Bank(2010) 편집

\section{2) 정부의 녹색 ODA 현황}

정부는 2009년 7월 국가 녹색성장 전략 및 5개년 계획을 통해 세계적인 녹색성장 모범국가 구현을 위하여 2020년까지 녹색 ODA 규모를 전체의 $30 \%$ 까지 확대키로 하였다. 본 계획의 일 환으로 코이카는 아시아 개도국의 기후변화대응 및 녹색성장 이행을 위하여 “동아시아기후파 트너십”(East Asia Climate Partnership, 이하 EACP) 사업을 2008-2012년간 2억불 규모로 수행하였다. 이는 대한민국 최초의 대 개도국 기후변화분야 국제 이니셔티브 사업으로서, 본 사업을 통해 한국의 개도국 기후변화 대응 관련 글로벌 노력에 동참하고, 녹색성장 선도국으 로서 국격 제고에 이바지 하는 동시에, “글로벌 녹색성장 연구소”(Global Green Growth Institution, 이하 GGGI)국제기구화 및 “녹색기후기금” (Green Climate Fund, 이후 GCF) 기 금 유치 홍보 등에도 기여한 대표적인 기후변화 대응사업이다.

한국 정부는 개발도상국의 지속 가능한 성장 정책 수립을 지원하는 GGGI를 2009년 설립하 여 전 세계 공조에 이바지 하였다. GGGI는 2012년 국제기구로 전환됨에 따라, 향후 개도국의 녹색성장 전략 및 정책 연구에 주도적 역할을 수행할 것으로 예상된다. 2012년에는 유엔지속 가능발전 정상회의(Rio+20)에서 $\mathrm{EACP}$ 사업의 후속으로 글로벌 녹색성장 파트너십(Global Green Growth Partnership)을 발표하고, 개도국의 녹색성장 및 지속가능발전을 위해 2020 년까지 50 억불 지원을 약속하였다. 또한 향후 한국 정부는 전략(GGGI, 글로벌녹색성장연구 소), 기술(GTC, 녹색기술센터), 재원(GTC, 녹색기후기금)이 유기적으로 작동하는 그린 트라 
이앵글(Green Triangle)을 제안함으로써, 한국이 개도국 기후변화 해결을 위한 글로벌 선도 체계를 제시함으로써, 한국의 녹색 리더십을 보여주는 계기가 되었다.

'12년 10월 송도에서 열린 $\mathrm{GCF}$ (녹색기후기금) 2차 이사회를 통해 인천 송도시가 사무국으 로 선정되었다. 저개발국의 기후변화 대응과 녹색경제 달성을 목표로 GCF는 2020년까지 1,000 억 달러 규모의 기금이 조성될 예정이다. 향후 녹색 $\mathrm{ODA}$ 의 상당부분은 새로 출범하는 $\mathrm{GCF}$ 재원으로 사용될 것으로 전망되고 있다. $\mathrm{GCF}$ 의 한국 유치는 기후변화 재정·금융의 중심 지로 도약하는 계기를 마련하는 계기가 되었으며, 이를 통해 한국이 선진국과 개도국간의 가 교적 역할 및 개도국의 녹색성장을 견인하는 글로벌 리더로서 전 세계의 주목을 받고 있다.

최근에는 녹색성장 정책과 지식, 정보의 공유를 위한 국제네트워크도 구축되었다. 2012.1.17 멕시코에서 GGGI, OECD, UNEP, World Bank 등 4개 국제기구가 녹색성장 이론 및 정책 등 에 관한 연구를 목적으로 '녹색성장지식플랫폼' GGKP : Green Growth Knowledge Platform) 을 구축키로 양해각서를 맺었다. 녹색 성장과 녹색 경제를 각각 조직의 주요정책으로 표방한 $\mathrm{OECD}$ 와 UNEP, 기후변화 재원의 핵심이자 GCF 기금 관리 주체인 WB가 함께 GGGI와 연합 함으로써, 아직 이해도가 낮은 녹색성장 관련 지식과 정보를 총합하고, 녹색 성장의 글로벌 컨 센서스 공유 및 다양한 정책 사례를 제시함으로써, 녹색성장 인식 제고와 이행 방안에 크게 기 여할 것으로 기대된다.

주요 녹색 다자기금에 대한 기여도 확대되고 있다. 지구환경기금(GEF)에 2010-2014년 750 만 달러, 아시아개발은행(ADB) 미래탄소펀드 2010-2013년 2,000만 달러, 세계은행(WB) 한 국 녹색성장협력 신탁기금 설치 2012-2015년 4,000만 달러 등을 포함하였으며, 최근 GCF 유 치 조건으로서 2012년 200만 달러 지원에 이어 2013년부터 매년 100만 달러씩 2019년까지 700 만 달러의 운영비를 지원하고, 2014 년부터 4년간 매년 1천만 달러씩 총 4천만 달러를 기 여하기로 약속하였다. 


\section{6. 동아시아기후파트너십 성과 및 교훈}

\section{가. 동아시아파트너십 사업 현황}

2008년 7월 G8 확대정상회의에서 우리 정부는 녹색성장 ODA 사업 확대를 통해 개도국의 기후변화 대응 지원 및 녹색성장 선도국가로서의 성숙한 세계국가 이미지 구현을 목표로, 2012년까지 5년간 총 2억불 규모의 “동아시아기후파트너십(EACP : East Asia Climate partnership)” 사업을 추진키로 국제사회에 공약하였다.

주요 전략으로 (1) 기후변화 대응(파트너국가의 기후변화 적응·완화·대응 능력 강화), (2) 녹색성장 공유(파트너국가와 경제성장 - 기후변화 대응의 선순환 형성 및 신성장 패러다임으로 녹색성장 전략을 파트너국가와 공유 (3) 국제협력 강화(기후변화 대응 파트너십으로 역내 국제 협력 제고)이다.

중점 지원 분야로서 아시아의 니즈, 우리의 역량 비교우위 등을 고려, 선택과 집중을 통한 5 개 분야 (1)물 관리 (2)저탄소 도시 (3)저탄소 에너지 (4)산림 (5)폐기물의 중점 지원분야를 선정 함으로써, 아시아의 기후변화 문제해결에 다각도로 기여하였다. 대상 국가는 중국, 인도 등을 제외한 아시아 개발도상국 전체를 대상으로 하였으며, 물랜드마크사업, 프로젝트형 등 주요 개발 사업은 10 개국 20 건 중심으로 수행하였다.

동아시아기후파트너십(EACP) 주요 사업유형은 물랜드마크사업, 프로젝트형 사업, 국내 초 청연수 사업, 기타 파트너십 및 인식증진 사업 등 개도국 기후변화 대응을 위한 종합 프로그램 형 지원 사업으로서 다양한 사업 형태를 활용하여, 지원 효과성 및 각 사업간 시너지 효과 향 상을 도모하였다. 


\section{〈표 8〉 동아시아기후파트너십 주요 현황}

【 물관리랜드마크사업 】

몽골, 필리핀, 아제르바이잔 3개국에 총 7,054 만불을 투입하여 수원국 물문제의 종합적 해결을 위한 대규모 사업 지원

【 프로젝트형 사업 】

10 개국 대상, 17 개 프로젝트형 원조(총 574억원) 사업으로서, 저탄소에너지, 물관리, 산림 및 폐기물, 저탄소도시 순으로 지원되었음. 상기 물랜드마크 사업 포함시 물분야가 최우선 지원 분야임.

\begin{tabular}{c|c|c|c|c}
\hline 물관리 & 저탄소에너지 & 저탄소도시 & 폐기물 & 산림 \\
\hline 3국 3건 & 7국 7건 & 1국 1건 & 3국 3건 & 3국 3건 \\
\hline 950만불 & 2,100만불 & 200만불 & 850만불 & 890만불 \\
\hline
\end{tabular}

【 국내 초청 연수사업 】

울관리 과정, 산림 과정, 녹색성장 과정 등 한국의 비교우위 분야 중심으로 16 개 과정을 운영, 고위급 및 정책 결정자 등 203명 초청을 실시하여 정책 노하우 전수

【기타 파트너십 및 인식증진 사업 】

○ 글로벌 녹색성장연구소(GGGI) 3개년간(2010-2012) 사업비 지원

○ $\mathrm{ADB}, \mathrm{ESCAP}, \mathrm{UNEP}, \mathrm{IMO}$ 등과 협력확대를 위해 13건 사업 진행

○ 동아시아기후포럼(글로벌녹색성장서밋으로 '11년부터 확대) 4회 등 실시

아시아 개도국 기후적응 정책연구 등 연구개발 20건

○ 국내외 홍보 등 녹색성장 인식증진 실시

\section{나. 동아시아파트너십 사업 성과}

한국 정부의 녹색성장 및 글로벌 녹색성장 파트너십에 대한 대표적인 이니셔티브로 아시아 녹색성장과 국제 협력개발을 위한 선진국-개도국 간 가교 역할을 수행하였으며, 파트너 국가 의 경제성장과 삶의 질 향상을 추구하며, 기후변화 대응과 지속 가능한 성장 추구를 위한 공적 개발원조 사업으로 의미가 크다고 할 수 있다. 주요 사업 성과는 아래와 같이 제시할 수 있다.

ㅁ우리 정부의 기후변화 및 녹색성장 의제 선도국으로서 녹색 리더십 확보 및 국 제적 위상 제고에 기여 
○ UN 기후변화협약 COP16 18차 회의 등에서 EACP Side Event, 부스 운영 등으로 한 국의 녹색 리더십 홍보

'09 '11년 언론보도 155 건 (국내 : 141 /국외 : 14), 보도자료 배포 14 회, 인터뷰 15 건, 기획기사 2 건 등

안국의 GCF 유치 활동, GGGI 국제기구화 등 기반 마련

다양한 국제기구들과 협력 사업을 통해 역내 정책결정자들의 기후변화 의제화 역량 강화, 개도국의 국가전략 입안 지침 제공, 국별 및 지역별 대응 역량 강화 등 도모

$\square$ 우리 나라 녹색 $\mathrm{ODA}$ 의 양적 및 질적 확대에 기여

○ 동아시아기후파트너십사업 추진 이후, KOICA 사업 중 녹색 ODA비중이 '08년 8.6\% 에서 '10년 $13.6 \%$, '13년 $15 \%$ 로 상승

$\circ \mathrm{KOICA}$ 녹색 ODA 사업비 중 신재생에너지 분야 비중은 $0 \%(' 09) \rightarrow 23.7 \%$ ('10)로 급증 하는 등 녹색성장 및 기후변화 분야 지원 사업 증대

무리나라 녹색성장의 비교우위 5 대 분야에 대한 전략적 선택과 집중을 통한 프 로그램 사업으로서의 성과 제고

○ 컨설팅을 통해 5 대 중점분야(물, 저탄소에너지, 저탄소 도시, 산림-바이오매스, 폐기 물) 선정 및 물랜드마크사업을 통해 사업 가시성 및 효과성 극대화

○ 다양한 형태의 사업수행(프로젝트형, 국제기구사업, 연구개발, 홍보, 대규모 물 관리 사업) 및 연계 등을 통해 프로그램형 사업수행 기반을 구축함

녹색분야 신성장동력 분야 우리 기업의 개도국 진출지원에 기여

물ㄹ 신재생에너지 등 5 대 분야 관련 기업 등 우리 기업의 ODA 사업을 통한 진출(중소 기업 28 개사, 대기업 5 개사 프로젝트 사업 참여)

대 개도국 녹색 $\mathrm{ODA}$ 지원 전문성 심화 및 조직역량 강화

○ KOICA는 기후변화 관련 사업 전담조직을 구성하여 $\mathrm{EACP}$ 사업을 수행하는 등 녹색 $\mathrm{ODA}$ 수행에서의 선도적인 역할을 수행하였음

○ 녹색 ODA에 대한 통계실적 정리, 연구 및 가이드라인 수립 등 기후변화 및 환경 ODA 수행 현황 분석 및 전략 수립 기반을 마련 


\section{다. 사업 교훈 및 과제}

$\mathrm{EACP}$ 사업은 영국, 일본 등 타 공여국과 비교하여, 지원 예산 규모는 크지 않지만, 여러 가지 개도국 기후변화 지원, 국격 제고 효과 등 다양한 성과 외에 지난 5 년간 사업 수행을 통한 주요 교훈 및 향후 과제를 아래와 같이 제시함으로써, 향후 유사 사업 수행에 시사점을 제공할 수 있다.

ㅁㅇㅠ.무상을 포괄한 국가 차원의 녹색 $\mathrm{ODA}$ 이행 로드맵 부재로 인해 전략적이 고 통합적 접근 미흡

욱별지원계획(CPS), 부처 간 조정, 통계 관리 등 국가 원조체계의 총괄틀 내에서 녹색 $\mathrm{ODA}$ 추진 필요

녹색기후기금(GCF) 유치, GGGI 국제기구화 등 우리나라의 국제적인 녹색 리더십 활 동과 연계 강화

$\mathrm{ODA}$ 정책 총괄기구인 국제개발협력위원회(위원장 : 국무총리)을 통해 "국가 녹색 ODA 로드맵(2013-2020)" 수립 필요

우리측 녹색 $\mathrm{ODA}$ 계획과 수원국의 녹색 정책 및 수요와 불일치할 경우, 지원 효과 저하

윽별로 상이한 녹색분야 정책, 시장 수요 등에 대한 고려를 바탕으로 지원 전략 수립 필요

언진 공여국의 유사 양자 이니셔티브에 비해, 지원 규모 및 대상 지역 등이 제한적

- 국별 소규모 시범 사업(pilot project) 보다 성과 중심의 중점 국가 중심의 대규모 프로그램(program) 사업 필요

국별 수요 발굴 등 원조 효과를 극대화할 수 있는 정책 및 시장 조사 등 개발 컨 설팅을 활용, 우수 프로그램 발굴 필요

마업 초기에 사업수행기관('08년 지경부 $\rightarrow 09$ 년 외교부) 변경, 복잡한 의사결정 체계 등으로 시행 착오 및 사업 지연 발생

$\circ \mathrm{EACP}$ 조정위원회(총리훈령)를 통한 복잡한 정책결정 구조로 인해 부처간 의견 조정 및 사업승인 지연 발생

○ 이로 인해 매년 공약 예산의 연 내 집행에 차질이 발생하여 예산 이월 등이 발생하는 등, 정책 결정구조와 예산 집행계획(사업 프로세스) 간의 괴리 발생

사업 초기 전략 수립시 사업 거버넌스, 정책 결정 단순화, 각 파트너십 주체의 역할 명확화, 예산과 정책연계 등 필요 
$\square$ 사업 수행 전후의 전체 프로그램 레벨의 성과 측정을 위한 전체 성과 평가틀 (Program Impact Framework) 필요

○ 녹색 $\mathrm{ODA}$ 패키지 사업 수행시, 사업 초기에 사업을 통한 지원 효과 관련 평가 요소, 정량 및 정성적 Indicator 개발 필요

사업 이행 단계에 모니터링 및 중간 성과 평가를 하여, 문제점 개선 및 교훈 피드백을 통해 사업 효과성 제고 필요

ㅁ 12 년 $\mathrm{EACP}$ 사업 종료에 따라, ' 13 년 이후 중장기적인 추가 재정 투입계획 부 재시 정부 녹색 $\mathrm{ODA}$ 목표 달성 불가능

○ 녹색 ODA에 대한 개도국의 낮은 수요 감안시, 2020년까지 녹색 ODA $30 \%$ 달성은 쉽 지 않을 전망

' 12.5 월 RIO+20에서 국제적 공약으로 발표한 글로벌녹색성장파트너십(GGGP)에서 발 표한 2020년까지 녹색 ODA 50억불까지 확대 방안 필요

GCF를 유치한 국제 녹색성장 선도국으로서의 리더십 발현을 위하여, 기존의 ODA 재원 외에 신규 추가 재원 투입을 통한 기후변화 특별 이니셔티브 사업 필요

\section{7. 향후 KOICA 녹색 ODA 방향}

향후 녹색 $\mathrm{ODA}$ 의 체계적인 추진을 위해 국제개발협력위원회(위원장 : 총리) 중심의 범정부 $\mathrm{ODA}$ 통합추진체계하에 전략적 녹색 ODA 추진체계를 마련할 계획이다5). 총리실, 기재부, 외 교부 등 관계부처 및 $\mathrm{KOICA}$ - 수출입은행 등 유관기관이 참여하는 "녹색 ODA 추진협의회"를 국제개발협력 실무위원회 산하 협의회로 설치하고, 매년 추진 결과를 국개위에 보고토록 할 예정이다. 이는 기존의 2008-2012년 녹색성장위원회가 주도로 추진되었으나 2013년 이후에 는 전체 $\mathrm{ODA}$ 의 틀 내에서 녹색 $\mathrm{ODA}$ 가 다뤄질 예정이다.

$\mathrm{KOICA}$ 는 2012년 EACP 종료 이후 2013년부터 (1) 정부의 글로벌녹색성장 파트너십 사업과 (2) KOICA 자체 녹색 ODA 추진 등 2 가지 방향으로 추진할 예정이다.

5) 제17차 녹색성장위원회 및 제8차 이행점검결과 보고대회, 글로벌 녹색성장 확산을 위한 녹색 ODA 발전방안, 2012.5.2 
〈표 9〉 녹색 ODA 추진체계 구성(안)

\begin{tabular}{|c|c|c|c|}
\hline & 기 존 & & 변 경 \\
\hline \multirow[t]{3}{*}{$\begin{array}{l}\text { 녹색 } \\
\text { ODA } \\
\text { 전반 }\end{array}$} & \multirow{3}{*}{$\begin{array}{l}\text { - 녹색위 중심 (별도 녹색 ODA 조 } \\
\text { 정위원회 부재) } \\
\text { - 무상 : 외교부(KOICA) } \\
\text { - 유상 : 기재부(수은) }\end{array}$} & \multirow{4}{*}{$\Longrightarrow$} & $\begin{array}{l}\text { - 국제개발협력위원회 } \\
\text { (위원장 : 국무총리) } \\
\text { - 실무위원회 } \\
\text { (위원장 : 국무차장) }\end{array}$ \\
\hline & & & $\uparrow$ (보고) \\
\hline & & & - 녹색 ODA 추진협의회 \\
\hline EACP & $\begin{array}{l}\text { - EACP 조정위원회 } \\
\text { * 위원장 : 국무총리실장 } \\
\text { * 소속 : 녹색성장위원회 }\end{array}$ & & $\begin{array}{l}\text { * 위원장 : 총리실 1급 } \\
\text { * 소속 : 총리실 } \\
\text { - 무상 : 외교부(KOICA) } \\
\text { - 유상 : 기재부(수은) } \\
\text { - 유·무상, 양자· 다자 및 } \\
\quad \text { 민관사업 등 연계 }\end{array}$ \\
\hline
\end{tabular}

첫째, '12.5월 RIO+20에서 2020년까지 녹색 ODA 50억불까지 확대를 국제적 공약으로 발 표한 글로벌녹색성장파트너십(GGGP) 이행을 위해서 국무총리실, 녹색 ODA 유관 부처 등과 협의해 나갈 예정이며, $\mathrm{KOICA}$ 는 동아시아기후파트너십의 사업 경험 및 성과를 바탕으로 사업 기획 및 수행에 주도적인 역할을 수행해 나갈 예정이다.

둘째, 녹색 ODA 활성화를 위해 개발협력사업 전반의 Cross-sector적 고려와 녹색 ODA 사 업으로서의 Sector적 측면을 동시에 고려한 Two-track approach를 통해 '13년부터 정부 장 기 목표인 2020년 녹색 ODA 30\% 목표 달성을 위해 적극 추진해 나갈 계획이다. 이는 녹색 $\mathrm{ODA}$ 브랜드화를 통해 기후변화 및 환경 분야사업의 체계적 관리 및 사업 강화 기반을 마련하 고, 전 코이카 개발원조 사업에 대한 ODA 녹색화를 포함한 환경 주류화를 통하여, 환경 및 기 후변화적 요소를 개발협력 정책에 적극 반영해 나갈 예정이다.

※ ODA 사업의 녹색화 사례

- (교육-의료 분야) 인프라 지원시 빗물 저장시설 및 신재생에너지 발전시설 설치, 친환경 자재·고단열재 사용한 에너지효율 제고 등

- (농업 분야) 토양침식방지 위한 피복작물 재배법 전수, 효율적인 물사용을 위한 수리시설 지원, 토양 유기영양분 공급 확대 등 


\section{참고문헌}

\section{국내 문헌}

임소진, 국제사회의 Post-2015 개발 프레임워크 수립동향 및 한국 ODA의 기여방안(KOICA, 2012)

이택근, “녹색 ODA 분류기준,"『국제개발협력』2011년 제3호 PP. 194-206

권율, 『국제사회의 개도국 녹색성장 지원현황 연구』(대외경제정책연구원, 2010)

전병성 외 9인, 『동아시아 개도국 기후변화유발 재해경감 및 GAP 극복방안 연구』(환경과문명, 2012)

유창민 외 8인, ${ }^{\circledR} \mathrm{KOICA}$ 녹색 ODA 활성화를 위한 마스터플랜 수립 연구 용역』(삼일회계법인, 2012)

정회성 외 9인, 『녹색 ODA 현황분석 및 활성화 방안 연구』(환경과문명, 2012)

『녹색성장 더 큰 대한민국』(대통령직속 녹색성장위원회, 2012)

\section{국외 문헌}

Richard Samans, Green Growth and the Post-2015 Development Agenda(GGGI, 2013)

OECD DAC, Putting green growth at the heart of development, 2013.4

Myung-Kyoon Lee, Green ODA : A better use of ODA for Green Growth, (GGGI,2012)

DARA, Climate Vulnerability Monitor 2nd Edition, 2012

UNEP, Moving Towards a Green Economy : Pathways for sustainable development and Poverty eradication, 2012

OECD DAC, Green Growth and Developing Countries : Consultation Draft, 2012.6

UNEP, Why a Green Economy Matters for the Least Developed Countries, 2011

OECD DAC, Towards Green Growth, 2011 